\title{
Determination of basal ileal endogenous losses and standardized ileal digestibility of amino acids in barley fed to growing pigs
}

Hanna Katharina Spindler ${ }^{1}$, Rainer Mosenthin ${ }^{1 *}$, Pia Rosenfelder ${ }^{1}$, Henry Jørgensen ${ }^{2}$, Knud Erik Bach Knudsen ${ }^{2}$ and Meike Eklund ${ }^{1}$

\begin{abstract}
Background: Basal ileal endogenous amino acid (AA) losses (IAA end $)$ and standardized ileal digestibility (SID) values of cereal grains, such as barley, are apparently underestimated when determined according to the nitrogen ( $N$ )-free method. Regression analysis between the dietary apparent ileal digestible content (CAID) and total crude protein (CP) and AA can be considered as alternative approach to obtain more accurate values for IAA end and SID of AA in cereal grains.
\end{abstract}

Methods: Eight hulled barley genotypes were used, with barley being the only source of CP and AA in the assay diets. The diets contained $95 \%$ as-fed of these eight barley genotypes each, ranging in CP content between 109. 1 and $123.8 \mathrm{~g} / \mathrm{kg}$ dry matter (DM). Nine ileally T-cannulated barrows, average body weight (BW) $30 \pm 2 \mathrm{~kg}$, were allotted to a row-column design comprising eight periods with $6 \mathrm{~d}$ each and nine pigs. On $\mathrm{d} 5$ and the night of $\mathrm{d} 6$ of every period, ileal digesta were collected for a total of $12 \mathrm{~h}$. The IAAend and the SID were determined by linear regression analysis between CAID and total dietary CP and AA.

Results: There exist linear relationships between CAID and total CP and AA $(P<0.001)$. The IAAend of CP, Lys, Met, Thr and Trp amounted to 35.34, 1.08, 0.25, 1.02 and $0.38 \mathrm{~g} / \mathrm{kg}$ DM intake (DMI), respectively, which are greater compared to average IAAend determined previously under N-free feeding conditions. The SID of CP, Lys, Met, Thr and Trp was 90, $79,85,79$ and $86 \%$, respectively, and was greater when compared to tabulated values. Moreover, these SID values were greater than those reported in literature, based on correction of apparent ileal digestibility (AID) of CP and AA for their IAA $A_{\text {end }}$ values. Summarized, the results of the present regression analysis indicate greater IAA $A_{\text {end }}$ in barley-based diets compared to those obtained by N-free feeding.

Conclusions: For low-protein feed ingredients like barley the regression method may be preferred over correction of AID values for their IAA $A_{\text {end }}$ determined under $\mathrm{N}$-free feeding conditions, as intercepts and slopes of the linear regression equations between CAID and total dietary CP and AA provide direct estimates of IAA end and SID of CP and AA in the presence of the assay feed ingredient.

Keywords: Amino acid, Barley, Basal ileal endogenous loss, Growing pigs, Regression analysis, Standardized ileal digestibility

\footnotetext{
*Correspondence: rainer.mosenthin@uni-hohenheim.de

'University of Hohenheim, Institute of Animal Science, Emil-Wolff-Strasse 10,

70599 Stuttgart, Germany

Full list of author information is available at the end of the article
} 


\section{Background}

About 308 million tons of cereals are annually harvested in the European Union [1]. Despite their low crude protein $(\mathrm{CP})$ content, they can supply more than half of the feed protein in pig diets due to their high dietary inclusion level [2]. Among different genotypes of the same cereal exists considerable variation both in contents and in standardized ileal digestibility (SID) of CP and amino acids (AA). For example, large standard deviations for SID of CP and Lys of 13.0 and $10.6 \%$, respectively, have been reported for barley [3]. Besides chemical composition, especially non-starch-polysaccharides (NSP), which may affect SID of CP and AA in cereals $[4,5]$, differences in basal ileal endogenous loss of $\mathrm{CP}$ and $\mathrm{AA}$ ( IAA $_{\text {end }}$ ) between different studies have been identified for being one of the major factors responsible for the observed variation in SID of CP and AA in cereals including barley [3].

The use of $\mathrm{N}$-free diets has been suggested as a routine procedure to generate SID values in feed ingredients [6]. With this method, Spindler et al. [7] determined relatively low SID of AA in barley amounting only to $74 \%$ for CP, and 67, 79, 73 and $75 \%$ for Lys, Met, Thr and Trp, respectively, compared to current nutrient tables. Nitrogen-free feeding, however, has in some cases been criticized to be not physiological, thereby resulting in smaller estimates of IAA $_{\text {end }}$ [8] when compared with the regression analysis method for determination of $\mathrm{IAA}_{\text {end }}$ in low-protein assay diets e.g. based on rye [9], triticale [10] or wheat [11]. Moreover, at low dietary CP and AA levels, such as in diets containing cereal grains as sole dietary CP source, correction of AID for IAA end $_{\text {. }}$ may result in quite variable SID of $\mathrm{CP}$ and AA $[12,13]$ due to a large and varying proportion of IAA $_{\text {end }}$ to total ileal CP and AA recovery. Regression analysis between the apparent ileal digestible and total dietary $\mathrm{CP}$ and AA content has been proposed to provide direct estimates of IAA $_{\text {end }}$ and SID of AA in the presence of graded dietary $\mathrm{CP}$ and AA levels from the assay feed ingredient $[3,12]$.

The regression method used in the present study allows for estimating $\mathrm{IAA}_{\text {end }}$ in pigs in the presence of eight barley genotypes different in $\mathrm{CP}$, by extrapolating the dietary $\mathrm{CP}$ and $\mathrm{AA}$ intakes to zero intake, and at the same time, estimates of SID of AA in barley can be derived from the slope of the regression analysis.

\section{Methods}

\section{Animal, diets and experimental design}

Nine crossbred barrows (Duroc $\times$ Landrace $\times$ Yorkshire), initial BW of $30 \pm 2 \mathrm{~kg}$, were housed individually in smooth sided pens with a concrete floor (area of $2.8 \mathrm{~m}^{2}$ ), and floor heating. The room was temperature-controlled $\left(22 \pm 2{ }^{\circ} \mathrm{C}\right)$. Water was available at all times. After $2 \mathrm{wk}$ of adaption, the pigs were surgically fitted with a simple T-cannula at the distal ileum. The pigs were allowed six to seven $\mathrm{d}$ of recuperation. Body weight of the pigs at the end of the experiment was $64 \pm 4 \mathrm{~kg}$. The animals were allotted to an $8 \times 9$ row-column design with eight periods of $6 \mathrm{~d}$ each and nine pigs.

Eight hulled winter barley genotypes, including Campanile (B1; LIMAGRAIN GmbH, Edemissen, Germany), Yool (B2; Syngenta Seeds GmbH, Bad Salzuflen, Germany), Lomerit (B3; KWS LOCHOW GmbH, Bergen, Germany), Travira (B4; Ackermann Saatzucht GmbH \& Co. KG, Irlbach, Germany), Anisette (B5; NORDSAAT Saatzucht-GmbH, Langenstein, Germany), Fridericus (B6; KWS LOCHOW GmbH, Bergen, Germany), Canberra (B7; LIMAGRAIN GmbH, Edemissen, Germany), and Metaxa (B8; Ackermann Saatzucht GmbH \& Co. KG, Irlbach, Germany) were used. The eight assay diets contained one of the eight barley genotypes each, thus barley was the only source of dietary CP and AA (Table 1). All diets had the same inclusion level of barley $(951.3 \mathrm{~g} / \mathrm{kg}$ as-fed). The barley batches were ground using a hammer mill (SKIOLD A/S, Sæby, Denmark) to pass a 2-mm sieve. A commercial mineral and vitamin premix, monocalcium phosphate, sodium chloride, and calcium carbonate were added to the assay diets to meet the NRC [14] nutrient requirements for pigs above $20 \mathrm{~kg}$. All assay diets were supplemented with plant oil at a level of $20 \mathrm{~g} / \mathrm{kg}$ (as-fed) to reduce the dustiness of the diets, and $0.2 \mathrm{~g} / \mathrm{kg}$ (as-fed) of DL- $\alpha$ tocopherol acetate was added as antioxidant. Titanium dioxide $(7 \mathrm{~g} / \mathrm{kg})$ was used as an indigestible marker. At the beginning of every period, the pigs where weighed and fed at a daily level of $40 \mathrm{~g} / \mathrm{kg}$ (as-fed) of average BW of all animals, corresponding to approximately 3

Table 1 Ingredient composition of the assay diets (g/kg, as-fed)

\begin{tabular}{lc}
\hline Item & Assay diets \\
\hline Barley $^{\mathrm{a}}$ & 951.3 \\
Oil $^{\mathrm{b}}$ & 20.0 \\
Vitamins and mineral mix $^{\mathrm{c}}$ & 16.2 \\
Monocalcium phosphate & 3.5 \\
Calcium carbonate & 1.8 \\
Vitamin E $^{\text {d }}$ & 0.2 \\
Titanium dioxide & 7.0
\end{tabular}

${ }^{a} n=$ eight genotypes of barley each

${ }^{b}$ Blend of rapeseed (75\%) and soybean oil ( $\left.25 \%\right)$

'Deutsche Vilomix Tierernährung GmbH, Neuenkirchen-Vörden, Germany.

Supplied per kg of diet: Ca, $4.0 \mathrm{~g} ; \mathrm{P}, 0.8 \mathrm{~g} ; \mathrm{Na}, 0.9 \mathrm{~g}$; Mg, $162 \mathrm{mg} ; \mathrm{Fe}, 65 \mathrm{mg}$ $\left(\mathrm{FeSO}_{4} \cdot \mathrm{H}_{2} \mathrm{O}\right) ; \mathrm{Cu}, 8 \mathrm{mg}\left(\mathrm{CuSO}_{4} \cdot 5 \mathrm{H}_{2} \mathrm{O}\right) ; \mathrm{Mn}, 43 \mathrm{mg}(\mathrm{MnO}) ; \mathrm{Zn}, 54 \mathrm{mg}(\mathrm{ZnO}) ; \mathrm{J}$, $1.1 \mathrm{mg}\left(\mathrm{Ca}\left(\mathrm{IO}_{3}\right)_{2}\right) ; \mathrm{Se}, 0.2 \mathrm{mg}\left(\mathrm{Na}_{2} \mathrm{SeO}_{3}\right) ; \mathrm{Co}, 0.1 \mathrm{mg}\left(2 \mathrm{CoCO}_{3} \cdot 3 \mathrm{Co}(\mathrm{OH})_{2} \cdot \mathrm{H}_{2} \mathrm{O}\right)$; Vitamin A, $6480 \mathrm{IU}$; Vitamin $\mathrm{D}_{3}, 972 \mathrm{IU}$; Vitamin $\mathrm{E}, 41 \mathrm{mg}$; Vitamin $\mathrm{B}_{1}, 1 \mathrm{mg}$; Vitamin $B_{2}, 3$ mg; Vitamin $B_{6}, 2$ mg; Vitamin $B_{12}, 16 \mu$; Vitamin $K_{3}, 2$ mg; Niacin, $10 \mathrm{mg}$; Ca-pantothenat, $6 \mathrm{mg}$; Folic acid, $0.4 \mathrm{mg}$; Choline chloride, $122 \mathrm{mg}$ dEuro OTC PHARMA GmbH, Bönen, Germany 
times their daily energy requirement for maintenance (i.e. $106 \mathrm{kcal}$ of $\mathrm{ME}$ (as-fed) $/ \mathrm{kg}$ of $\mathrm{BW}^{0.75}$; [14]).

\section{Experimental feeding and sample collection}

Feed was divided into two equal meals, and fed to pigs at 0800 and $2000 \mathrm{~h}$. The initial $4 \mathrm{~d}$ of every period were considered as an adaption period to the assay diets. During the initial $3.5 \mathrm{~d}$ of every period, a crystalline AA mixture (L-Gly, $775.1 \mathrm{~g} / \mathrm{kg}$ as-fed; L-Lys- $\mathrm{HCl}, 106.4 \mathrm{~g} / \mathrm{kg}$ as-fed; DL-Met, $15.9 \mathrm{~g} / \mathrm{kg}$ as-fed; L-Thr, $29.1 \mathrm{~g} / \mathrm{kg}$ as-fed; L-Trp, $5.1 \mathrm{~g} / \mathrm{kg}$ as-fed; L-Ile, $18.2 \mathrm{~g} / \mathrm{kg}$ as-fed; L-Leu, $25.7 \mathrm{~g} / \mathrm{kg}$ as-fed; L-Val, $16.0 \mathrm{~g} / \mathrm{kg}$ as-fed; L-His, $6.5 \mathrm{~g} / \mathrm{kg}$ as-fed; L-Phe, $2.0 \mathrm{~g} / \mathrm{kg}$ as-fed; the total amount of the AA mixture was adjusted to the daily feed allowance, and amounted to 50, 54, 59, 64, 69, 75, 81 and $87 \mathrm{~g} /$ feeding in periods one to eight, respectively) was added on top of the assay diets to attenuate the effect of feeding low-protein diets [15]. At the evening of $\mathrm{d} \mathrm{4,2} \mathrm{g} / \mathrm{kg}$ of chromic oxide was added to the assay diets to visually differentiate digesta originating from the assay diets without synthetic AA by their green color. Digesta was collected for a total of $12 \mathrm{~h}$ on $\mathrm{d} 5$ of period one, three, five, and seven from 1000 to 1200,1400 to 1600 , and 1800 to $2000 \mathrm{~h}$, and on d 6 of period one, three, five, and seven from 2000 to 2200, 2400 to 0200 , and 0400 to $0600 \mathrm{~h}$. Additionally, digesta collection was conducted on d 5 of period two, four, six, and eight from 0800 to 1000,1200 to 1400 , and 1600 to $1800 \mathrm{~h}$, and on d 6 of period two, four, six, and eight from 2200 to 2400, 0200 to 0400 , and 0600 to $0800 \mathrm{~h}$. Ileal digesta were collected in plastic bags. Bags were removed at least every $30 \mathrm{~min}$, and $4 \mathrm{~mL}$ of $2.5 \mathrm{~mol} / \mathrm{L}$ formic acid were added to every bag to minimize further bacterial fermentation. Digesta samples were pooled within pig and period and immediately frozen at $-20{ }^{\circ} \mathrm{C}$.

\section{Chemical analyses}

Digesta samples were freeze-dried, ground to $0.5 \mathrm{~mm}$, and homogenized before analyses. All chemical analyses were conducted as described by Rosenfelder et al. [16]. Methods of VDLUFA [17] were used to determine contents of dry matter (DM) in barley and in ileal digesta samples (method 3.1). Accordingly, ash content in barley was measured based on method 8.1, CP in barley with method 4.1.1, neutral detergent fiber (NDF) was assayed with heat-stable amylase exclusive of residual ash (aNDFom; method 6.5.1), and acid detergent fiber (ADF), also expressed exclusive of residual ash, (ADFom) according to method 6.5.2. Acid detergent lignin (ADL) was determined by solubilization of cellulose with sulphuric acid (ADL (sa); method 6.5.3), and starch according to the polarimetric method (7.2.1).

Non-starch polysaccharides, and Klason lignin in barley were determined by enzymatic-colorimetric and enzymatic-chemical-gravimetric methods as described by Bach Knudsen [18]. Klason lignin was determined by a two-stage sulfuric acid hydrolysis, and is supposed to be more accurate in estimating plant cell-wall lignin content than ADL [19-21]. Content of total and soluble arabinoxylan was determined as the sum of arabinose and xylose residues in total and soluble NSP. Total and insoluble $\beta$-glucans were analyzed by the enzymaticcolorimetric method of McCleary and Glennie-Holmes [22]. Soluble $\beta$-glucan was calculated as difference between total $\beta$-glucan and insoluble $\beta$-glucan after extraction of the soluble $\beta$-glucan in water [23].

Gross energy (GE) content in the eight barley genotypes was measured using a bomb calorimeter (IKA calorimeter, C200, IKA ${ }^{\circ}$-Werke GmbH \& Co. KG, Staufen, Germany). Nitrogen $(\mathrm{N})$ contents in the eight assay diets, and digesta samples were analyzed using a gas combustion method according to the official method 990.03 of the AOAC [24]. Crude protein content was calculated by multiplying the content of $\mathrm{N}$ with 6.25. Ethlyenediaminetetraacetic acid was used as a reference standard before and after all $\mathrm{N}$ analyses. Amino acid contents in the barley genotypes, assay diets and digesta samples were determined by using ion-exchange chromatography with postcolumn derivatization with ninhydrin. The AA were oxidized with performic acid which was neutralized by sodium metabisulfite $[25,26]$. They were hydrolyzed by means of $6 \mathrm{~mol} / \mathrm{L} \mathrm{HCl}$ for $24 \mathrm{~h}$ at $110^{\circ} \mathrm{C}$. Thereafter, they were quantified with the internal standard method (norleucine) by measuring the absorption of reaction products with ninhydrin at $570 \mathrm{~nm}$. Tryptophan was determined by HPLC with fluorescence detection (extinction $280 \mathrm{~nm}$, emission $356 \mathrm{~nm}$ ) after alkaline hydrolysis with barium hydroxide octahydrate for $20 \mathrm{~h}$ at $110{ }^{\circ} \mathrm{C}$ [27]. Concentrations of titanium dioxide in the assay diets and the ileal digesta samples were determined according to a method outlined by Brandt and Allam [28].

\section{Calculations}

The apparent ileal digestible content (cAID) of $\mathrm{CP}$ and $\mathrm{AA}$ in the assay diets were calculated according to the equation:

$$
\mathrm{cAID}=\mathrm{AA}_{\text {diet }}-\left[\left(\mathrm{Ti}_{\text {diet }} \times \mathrm{AA}_{\text {digesta }}\right) / \mathrm{Ti}_{\text {digesta }}\right]
$$

where cAID = apparent ileal digestible content of $\mathrm{CP}$ or $\mathrm{AA}$ in the assay diet $(\mathrm{g} / \mathrm{kg} \mathrm{DMI}) ; \mathrm{AA}_{\text {diet }}=\mathrm{CP}$ or $\mathrm{AA}$ content in the assay diet $(\mathrm{g} / \mathrm{kg} \mathrm{DMI}) ; \mathrm{Ti}_{\text {diet }}=$ marker content in the assay diet $(\mathrm{g} / \mathrm{kg} \mathrm{DM}) ; \mathrm{AA}_{\text {digesta }}=\mathrm{CP}$ or AA content in ileal digesta $(\mathrm{g} / \mathrm{kg} \mathrm{DMI})$, and $\mathrm{Ti}_{\text {digesta }}=$ marker content in ileal digesta $(\mathrm{g} / \mathrm{kg} \mathrm{DM})$.

For determination of IAA $_{\text {end }}$ and SID of CP and AA, a simple linear regression model was used. The relationship between SID and apparent ileal digestibility (AID) 
of $\mathrm{CP}$ and $\mathrm{AA}$ in the assay diet can either be expressed by Eq. (2) or, after further mathematical derivation, by Eq. (3):

$$
\begin{aligned}
& \mathrm{SID}=\left[\left(\mathrm{cAID} / \mathrm{AA}_{\text {diet }}\right)+\left(\mathrm{IAA}_{\text {end }} / \mathrm{AA}_{\text {diet }}\right)\right] \\
& \mathrm{cAID}=-\mathrm{IAA}_{\text {end }}+\left[(\mathrm{SID} / 100) \times \mathrm{AA}_{\text {diet }}\right]
\end{aligned}
$$

where SID = standardized ileal digestibility of $\mathrm{CP}$ or AA in the assay diet and barley; cAID = cAID of CP or AA in assay diet, determined using Eq. 1; $\mathrm{AA}_{\text {diet }}=$ total content of $\mathrm{CP}$ or $\mathrm{AA}$ in the assay diet $(\mathrm{g} / \mathrm{kg} \mathrm{DMI})$;
$\mathrm{IAA}_{\text {end }}=$ basal ileal endogenous $\mathrm{CP}$ and AA losses $(\mathrm{g} / \mathrm{kg}$ DMI). Contents of apparent ileal digestible $\mathrm{CP}$ and AA are dependent, and $\mathrm{AA}_{\text {diet }}$ are independent variables [12]. The regression coefficients $\mathrm{IAA}_{\text {end }}$ and SID of CP and AA are estimated by fitting the linear regression model. If relationships between cAID and total content of $\mathrm{CP}$ and $\mathrm{AA}$ in the assay diets are linear, dietary $\mathrm{CP}$ and $\mathrm{AA}$ intakes can be extrapolated to zero intake for determination of $\mathrm{IAA}_{\text {end }}$. Furthermore, SID in the assay diets and barley is represented by the slope of the linear regression model $[3,13]$.

\begin{tabular}{|c|c|c|c|c|c|c|c|c|}
\hline Item & B1 & B2 & B3 & B4 & B5 & B6 & B7 & B8 \\
\hline $\mathrm{CP}$ & 118.9 & 112.6 & 117.3 & 116.6 & 127.4 & 129.2 & 125.9 & 128. \\
\hline \multicolumn{9}{|c|}{ Indispensable AA } \\
\hline Arg & 6.0 & 5.7 & 5.8 & 6.1 & 6.2 & 6.5 & 6.5 & 6.3 \\
\hline His & 2.6 & 2.5 & 2.6 & 2.6 & 2.6 & 2.9 & 2.6 & 2.6 \\
\hline Ile & 4.3 & 3.9 & 4.2 & 3.8 & 4.5 & 4.4 & 4.2 & 4.2 \\
\hline Leu & 8.1 & 7.7 & 7.7 & 8.0 & 8.7 & 8.9 & 8.9 & 8.9 \\
\hline Lys & 4.1 & 4.0 & 4.0 & 4.5 & 4.1 & 4.4 & 4.5 & 4.3 \\
\hline Met & 1.9 & 1.8 & 1.9 & 1.8 & 2.1 & 2.1 & 2.1 & 2.1 \\
\hline Phe & 5.7 & 5.7 & 5.7 & 5.6 & 6.8 & 6.5 & 6.4 & 6.9 \\
\hline Thr & 3.9 & 3.9 & 3.9 & 4.1 & 4.2 & 4.3 & 4.2 & 4.2 \\
\hline Trp & 1.4 & 1.5 & 1.4 & 1.5 & 1.6 & 1.6 & 1.6 & 1.6 \\
\hline Val & 5.9 & 5.5 & 5.9 & 5.7 & 6.2 & 6.3 & 6.1 & 5.9 \\
\hline
\end{tabular}

Table 2 Chemical composition of the eight barley genotypes ( $\mathrm{g} / \mathrm{kg}$ dry matter)

\begin{tabular}{|c|c|c|c|c|c|c|c|c|}
\hline Ala & 4.7 & 4.4 & 4.7 & 4.9 & 4.8 & 5.0 & 4.9 & 4.9 \\
\hline Asp & 7.1 & 6.7 & 6.7 & 7.2 & 7.1 & 7.5 & 7.4 & 7.2 \\
\hline Cys & 2.4 & 2.5 & 2.5 & 2.7 & 2.6 & 2.7 & 3.0 & 2.9 \\
\hline Glu & 28.6 & 26.3 & 28.4 & 26.1 & 31.9 & 31.8 & 29.6 & 30.9 \\
\hline Gly & 4.6 & 4.8 & 4.7 & 5.1 & 4.8 & 5.5 & 5.1 & 5.0 \\
\hline Pro & 12.8 & 11.7 & 12.5 & 11.5 & 14.6 & 14.5 & 13.4 & 14.4 \\
\hline Ser & 5.1 & 4.9 & 5.0 & 5.1 & 5.5 & 5.5 & 5.5 & 5.4 \\
\hline Dry matter & 879.0 & 878.0 & 880.0 & 877.0 & 879.0 & 881.0 & 882.0 & 882.0 \\
\hline Gross energy MJ/kg DM & 18.7 & 18.7 & 18.7 & 18.7 & 18.8 & 19.1 & 17.7 & 18.8 \\
\hline Starch & 560.0 & 564.0 & 545.0 & 548.0 & 541.0 & 533.0 & 546.0 & 550.0 \\
\hline$\beta$-glucan & 39.5 & 50.3 & 43.9 & 45.7 & 53.3 & 43.3 & 49.9 & 48.2 \\
\hline Soluble $\beta$-glucan & 20.6 & 27.0 & 20.3 & 24.8 & 25.8 & 24.4 & 26.6 & 23.5 \\
\hline Arabinoxylan & 81.1 & 74.4 & 75.5 & 75.7 & 70.5 & 76.6 & 86.4 & 78.8 \\
\hline Soluble arabinoxylan & 7.2 & 4.0 & 6.5 & 10.4 & 7.4 & 7.1 & 20.1 & 14.7 \\
\hline Total NSP & 171.1 & 168.0 & 176.7 & 167.0 & 168.3 & 168.4 & 184.1 & 172.7 \\
\hline Soluble NSP & 40.3 & 46.1 & 50.5 & 49.9 & 55.4 & 37.6 & 66.1 & 58.6 \\
\hline Klason lignin & 26.9 & 20.1 & 20.7 & 15.2 & 24.5 & 27.4 & 22.9 & 18.9 \\
\hline aNDFom & 180.2 & 207.7 & 209.1 & 205.3 & 191.1 & 194.1 & 181.4 & 182.5 \\
\hline ADFom & 52.6 & 51.3 & 56.3 & 50.5 & 44.5 & 63.4 & 52.9 & 46.2 \\
\hline ADL (sa) & 8.9 & 8.7 & $<0.5$ & 8.0 & 4.8 & 7.9 & 8.5 & 6.6 \\
\hline
\end{tabular}

Dispensable AA 


\section{Statistical analysis}

Linear regression analysis between CAID of CP and AA and the dietary $\mathrm{CP}$ and AA content was used to test homogeneity of variances, normal distribution of the data and to detect outliners by analysis of the studentized residuals using the UNIVARIATE procedure of SAS [29]. The cAID of CP and AA of every assay diet were analyzed using the MIXED procedure of SAS. The results on CAID of CP and AA were reported as least squares means. Linear and quadratic regression analyses between dietary apparent ileal digestible and total $\mathrm{CP}$ and AA contents were conducted, and the best structure according to the Akaike Information Criterion was selected. Thereafter, linear regression analyses between cAID and total CP and AA in the diets were performed, to determine IAA $_{\text {end }}$ and SID of CP and AA in barley batches. All models included the fixed effect of dietary $\mathrm{CP}$ and (or) AA level and animal, whereas period and period $\times$ pig were considered random effects. Linear regression analyses were performed on effects of chemical composition on SID of CP and AA. For all Wald-type F-tests the significance level was set at $\alpha=0.05$.

\section{Results}

\section{General observations}

All pigs remained healthy and readily consumed their daily feed allowances. Occasional feed refusals were recorded. A total of four outliers were detected across all eight dietary treatments, and these observations were therefore removed from the data set before further statistical analyses. Finally, a total of 68 observations were included in the model for estimation of $\mathrm{IAA}_{\text {end }}$ and determination of SID of CP and AA in barley genotypes.

\section{Chemical composition of the barley genotypes and contents of apparent ileal digestible CP and AA in the barley-based assay diets}

The chemical composition of the eight barley genotypes is shown in Table 2. Their contents of CP, Lys, Met, Thr, and Trp ranged from 112.6 to $129.2,4.0$ to $4.5,1.8$ to $2.1,3.9$ to 4.3 , and 1.4 to $1.6 \mathrm{~g} / \mathrm{kg} \mathrm{DM}$, respectively, whereas contents of starch, aNDFom, ADFom, ADL (sa), and NSP varied from 533.0 to $564.0,180.2$ to 209.1, 44.5 to $63.4,<5.0$ to 8.9 , and 168.0 to $184.1 \mathrm{~g} / \mathrm{kg} \mathrm{DM}$, respectively. All diets had the same inclusion level of barley, and due to the different $\mathrm{CP}$ contents in the eight barley genotypes, CP contents increased from 109.1 to $123.8 \mathrm{~g} / \mathrm{kg}$ DM from assay diets B1 to B8 (Table 3). Contents of apparent ileal digestible AA ( $\mathrm{g} / \mathrm{kg}$ of DMI) in the assay diets are presented in Table 4 . In response to the increase in dietary CP level from 109 to $124 \mathrm{~g} / \mathrm{kg}$ $\mathrm{DM}$, the apparent ileal digestible $\mathrm{CP}$ and AA contents linearly increased $(P<0.01$, except for Gly $(P<0.05))$.
Table 3 Contents of crude protein (CP) and amino acids (AA) in the barley-based assay diets ( $\mathrm{g} / \mathrm{kg}$ dry matter)

\begin{tabular}{cllllllll}
\hline Item & B1 & B2 & B3 & B4 & B5 & B6 & B7 & B8 \\
\hline CP & 109.1 & 109.6 & 109.6 & 114.2 & 117.5 & 120.4 & 122.1 & 123.8 \\
\multicolumn{1}{l}{ Indispensable AA } & & & & & & \\
Arg & 5.5 & 5.9 & 5.1 & 5.6 & 6.0 & 5.9 & 5.9 & 6.1 \\
His & 2.4 & 2.5 & 2.2 & 2.4 & 2.4 & 2.6 & 2.6 & 2.5 \\
Ile & 3.5 & 3.7 & 3.7 & 4.0 & 3.9 & 3.8 & 4.4 & 4.0 \\
Leu & 7.4 & 7.8 & 6.9 & 7.6 & 8.2 & 8.1 & 8.4 & 8.6 \\
Lys & 4.0 & 4.1 & 3.5 & 3.8 & 4.1 & 4.1 & 4.0 & 4.2 \\
Met & 1.7 & 1.8 & 1.7 & 1.8 & 1.8 & 1.8 & 2.0 & 1.9 \\
Phe & 5.1 & 5.6 & 4.9 & 5.3 & 5.9 & 6.2 & 6.2 & 6.6 \\
Thr & 3.7 & 3.9 & 3.6 & 3.6 & 3.9 & 4.1 & 4.0 & 4.1 \\
Trp & 1.5 & 1.5 & 1.4 & 1.4 & 1.6 & 1.6 & 1.6 & 1.6 \\
Val & 5.3 & 5.4 & 5.0 & 5.4 & 5.4 & 5.5 & 6.1 & 5.7 \\
Dispensable AA & & & & & & & \\
Ala & 4.4 & 4.6 & 4.1 & 4.4 & 4.5 & 4.6 & 4.6 & 4.7 \\
Asp & 6.5 & 6.9 & 5.9 & 6.5 & 6.9 & 6.9 & 6.8 & 6.9 \\
Cys & 2.5 & 2.5 & 2.2 & 2.3 & 2.7 & 2.6 & 2.6 & 2.8 \\
Glu & 24.1 & 26.1 & 26.0 & 27.1 & 26.7 & 28.4 & 30.1 & 29.5 \\
Gly & 4.6 & 4.8 & 4.1 & 4.3 & 4.6 & 5.0 & 4.5 & 4.7 \\
Pro & 10.9 & 11.7 & 11.5 & 12.0 & 12.5 & 13.2 & 13.9 & 14.1 \\
Ser & 4.6 & 4.8 & 4.6 & 4.9 & 5.0 & 5.1 & 5.1 & 5.2 \\
\hline
\end{tabular}

For some AA, there were also quadratic increases, however, the linear regression model fitted in all cases better than the quadratic one, which was reflected in smaller Akaike Information Criterion values in the linear compared to the quadratic model (data not shown).

\section{Basal ileal endogenous losses and standardized ileal} digestibility of CP and AA in the barley-based assay diets Due to significant linear relationships between contents of apparent ileal digestible and total $\mathrm{CP}$ and AA in the assay diets $(P<0.001)$, both IAA $_{\text {end }}$, and SID of $\mathrm{CP}$ and $\mathrm{AA}$ in the barley genotypes can be derived from the results of the regression analysis. Moreover, intercepts and slopes of the linear regression equations provide direct estimates of IAA $_{\text {end }}$ and SID of CP and

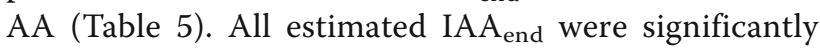
different from zero $(P<0.05)$. Basal ileal endogenous loss of $\mathrm{CP}$ and $\mathrm{AA}$, obtained by extrapolating dietary $\mathrm{CP}$ and AA levels to zero intake, was 35.34, 1.08, 0.25, 1.02, and $0.38 \mathrm{~g} / \mathrm{kg}$ DMI for CP, Lys, Met, Thr, and Trp respectively. Overall, $\mathrm{IAA}_{\text {end }}$ ranged from $0.25 \mathrm{~g} / \mathrm{kg}$ DMI (Met) to $1.29 \mathrm{~g} / \mathrm{kg}$ DMI (Leu) for indispensable and from $0.43 \mathrm{~g} / \mathrm{kg}$ DMI (Cys) to $3.44 \mathrm{~g} / \mathrm{kg}$ DMI (Glu) for dispensable AA. The slopes of all linear regression 
Table 4 Contents of apparent ileal digestible crude protein (CP) and amino acids (AA; LSMeans \pm SEM, g/kg dry matter intake) in barley-based assay diets fed to growing pigs

\begin{tabular}{|c|c|c|c|c|c|c|c|c|c|}
\hline Item & B1 & B2 & B3 & B4 & B5 & B6 & B7 & B8 & $P$-value* \\
\hline$\overline{n^{a}}$ & 9 & 9 & 9 & 7 & 8 & 9 & 8 & 9 & \\
\hline $\mathrm{CP}$ & $65.2 \pm 1.18$ & $72.9 \pm 1.17$ & $69.1 \pm 1.17$ & $62.4 \pm 1.18$ & $74.8 \pm 1.18$ & $73.9 \pm 1.18$ & $80.0 \pm 1.17$ & $76.6 \pm 1.09$ & $<0.001$ \\
\hline \multicolumn{10}{|c|}{ Indispensable AA } \\
\hline Arg & $4.2 \pm 0.05$ & $4.1 \pm 0.05$ & $3.7 \pm 0.05$ & $3.9 \pm 0.05$ & $4.2 \pm 0.05$ & $4.5 \pm 0.05$ & $4.6 \pm 0.05$ & $4.2 \pm 0.04$ & $<0.001$ \\
\hline His & $1.2 \pm 0.02$ & $1.7 \pm 0.02$ & $1.6 \pm 0.02$ & $1.6 \pm 0.02$ & $1.8 \pm 0.02$ & $1.7 \pm 0.02$ & $1.8 \pm 0.02$ & $1.8 \pm 0.02$ & $<0.001$ \\
\hline lle & $2.4 \pm 0.03$ & $2.7 \pm 0.03$ & $2.5 \pm 0.03$ & $2.1 \pm 0.03$ & $3.0 \pm 0.03$ & $2.6 \pm 0.03$ & $2.6 \pm 0.03$ & $2.5 \pm 0.03$ & $<0.001$ \\
\hline Leu & $5.4 \pm 0.06$ & $5.4 \pm 0.06$ & $4.9 \pm 0.06$ & $5.0 \pm 0.06$ & $5.9 \pm 0.06$ & $5.9 \pm 0.06$ & $6.2 \pm 0.06$ & $5.8 \pm 0.06$ & $<0.001$ \\
\hline Lys & $2.2 \pm 0.05$ & $2.1 \pm 0.05$ & $1.8 \pm 0.05$ & $2.0 \pm 0.05$ & $2.1 \pm 0.05$ & $2.3 \pm 0.05$ & $2.3 \pm 0.05$ & $2.2 \pm 0.05$ & $<0.001$ \\
\hline Met & $1.3 \pm 0.01$ & $1.3 \pm 0.01$ & $1.2 \pm 0.01$ & $1.1 \pm 0.01$ & $1.5 \pm 0.01$ & $1.3 \pm 0.01$ & $1.4 \pm 0.01$ & $1.3 \pm 0.01$ & $<0.001$ \\
\hline Phe & $3.9 \pm 0.05$ & $3.7 \pm 0.05$ & $3.4 \pm 0.05$ & $3.3 \pm 0.05$ & $4.4 \pm 0.05$ & $4.2 \pm 0.05$ & $4.8 \pm 0.05$ & $4.5 \pm 0.05$ & $<0.001$ \\
\hline Thr & $2.2 \pm 0.05$ & $1.9 \pm 0.05$ & $2.0 \pm 0.05$ & $1.9 \pm 0.05$ & $2.1 \pm 0.05$ & $2.1 \pm 0.05$ & $2.3 \pm 0.05$ & $2.3 \pm 0.05$ & $<0.001$ \\
\hline Trp & $0.8 \pm 0.02$ & $0.8 \pm 0.02$ & $0.7 \pm 0.02$ & $0.8 \pm 0.02$ & $0.9 \pm 0.02$ & $0.9 \pm 0.02$ & $0.9 \pm 0.02$ & $0.9 \pm 0.01$ & $<0.001$ \\
\hline Val & $3.5 \pm 0.05$ & $3.7 \pm 0.05$ & $3.4 \pm 0.05$ & $3.4 \pm 0.05$ & $4.2 \pm 0.05$ & $3.7 \pm 0.05$ & $3.8 \pm 0.05$ & $3.7 \pm 0.04$ & $<0.001$ \\
\hline \multicolumn{10}{|c|}{ Dispensable AA } \\
\hline Ala & $2.5 \pm 0.06$ & $2.4 \pm 0.06$ & $2.2 \pm 0.06$ & $2.2 \pm 0.06$ & $2.4 \pm 0.06$ & $2.5 \pm 0.06$ & $2.7 \pm 0.06$ & $2.5 \pm 0.06$ & $<0.001$ \\
\hline Asp & $3.9 \pm 0.08$ & $3.7 \pm 0.08$ & $3.1 \pm 0.08$ & $3.4 \pm 0.08$ & $3.6 \pm 0.08$ & $4.0 \pm 0.08$ & $3.9 \pm 0.08$ & $3.8 \pm 0.08$ & $<0.001$ \\
\hline Cys & $1.7 \pm 0.02$ & $1.6 \pm 0.02$ & $1.6 \pm 0.02$ & $1.7 \pm 0.02$ & $1.8 \pm 0.02$ & $2.0 \pm 0.02$ & $2.1 \pm 0.02$ & $1.9 \pm 0.02$ & $<0.001$ \\
\hline Glu & $20.6 \pm 0.15$ & $22.4 \pm 0.14$ & $21.6 \pm 0.14$ & $18.7 \pm 0.15$ & $25.1 \pm 0.15$ & $21.6 \pm 0.15$ & $24.1 \pm 0.14$ & $23.4 \pm 0.13$ & $<0.001$ \\
\hline Gly & $2.2 \pm 0.10$ & $1.8 \pm 0.10$ & $1.7 \pm 0.10$ & $2.0 \pm 0.10$ & $1.8 \pm 0.10$ & $2.2 \pm 0.10$ & $2.3 \pm 0.10$ & $2.5 \pm 0.09$ & 0.025 \\
\hline Pro & $8.1 \pm 0.22$ & $8.8 \pm 0.22$ & $8.5 \pm 0.22$ & $7.4 \pm 0.22$ & $10.2 \pm 0.22$ & $9.1 \pm 0.22$ & $10.8 \pm 0.22$ & $9.8 \pm 0.20$ & $<0.001$ \\
\hline Ser & $3.1 \pm 0.06$ & $3.2 \pm 0.05$ & $3.0 \pm 0.05$ & $2.8 \pm 0.05$ & $3.3 \pm 0.05$ & $3.3 \pm 0.05$ & $3.5 \pm 0.05$ & $3.3 \pm 0.05$ & $<0.001$ \\
\hline
\end{tabular}

*P-value for linear effect

${ }^{a} n=$ number of pigs per treatment

equations which represent SID values for $\mathrm{CP}$ and $\mathrm{AA}$, were significant $(P<0.001)$ and amounted to 90,79 , 85, 79 and $86 \%$ for CP, Lys, Met, Thr and Trp, respectively. Overall, SID values ranged from 79 (Lys) to $93 \%$ (Arg and Ile) for indispensable and from 77 (Ala) to $95 \%$ (Pro) for dispensable AA.

\section{Discussion}

There were only small variations in the chemical composition of the eight barley genotypes, as indicated by small coefficient of variation, and these variations had only minor impact on SID of AA in these genotypes [7]. The average $\mathrm{CP}$ and AA contents of the barley genotypes were within the range of values reported by NRC [30]. Contents of aNDFom and ADFom of the barley genotypes were in the range of NDF and ADF values reported in current feed tables for barley [30]. Contents of NSP were greater than values obtained by Baidoo and Liu [31] for both hulled and hulless barley, whereas contents of $\beta$-glucan and arabinoxylan were similar to values reported for hulless barley [31, 32].

The IAA $\mathrm{A}_{\text {end }}$ values represented in the present study by the intercept of regression analyses between cAID and dietary contents of $\mathrm{CP}$ and $\mathrm{AA}$, were substantially greater than average $\mathrm{IAA}_{\text {end }}$ obtained from $\mathrm{N}$-free feeding as summarized by Jansman et al. [8] (e.g. for CP 35.3 vs $11.8 \mathrm{~g} / \mathrm{kg}$ DMI and for Lys 1.1 vs $0.4 \mathrm{~g} / \mathrm{kg}$ DMI). Similarly, regression analysis revealed also greater IAA $_{\text {end }}$ in cereal-based diets compared with $\mathrm{N}$-free feeding in earlier studies (e.g. [33]). These findings have been confirmed in recently published reports by Eklund et al. [9] for rye, Rosenfelder et al. [11] for wheat, and Strang et al. [10] for triticale, where $\mathrm{IAA}_{\text {end }}$ were considerably greater than average values reported for $\mathrm{N}$-free feeding [8]. Moreover, Fan and Sauer [34], Pedersen et al. [35], and Spindler et al. [3] reported also greater $\mathrm{IAA}_{\text {end }}$ in barley-based diets determined by the same method of regression analysis as in the present study compared to $\mathrm{N}$-free feeding. Several factors are known to be responsible for the large differences in the endogenous $\mathrm{CP}$ and AA outputs among studies. These factors include among others variations in the range of dietary $\mathrm{CP}$ levels used for regression analysis [13, 36], the physiological status of the pig [37] but also the use of different methods for estimating $\mathrm{IAA}_{\text {end }}$ values $[38,39]$, and contents and types of dietary fiber in the assay diets $[39,40]$.

According to Fan et al. [12], the closer the graded dietary levels of $\mathrm{CP}$ and $\mathrm{AA}$ to the origin of the coordinate, the 
Table 5 Standardized ileal digestibility (SID) of crude protein (CP) and amino acids (AA; \%) and basal ileal endogenous losses (IAA end; $\mathrm{g} / \mathrm{kg}$ dry matter intake) in the barley genotypes $(n=68)$

\begin{tabular}{lllll}
\hline Item & SID \pm SEM & $P$-value & IAA And $^{*}$ SEM & $P$-value \\
\hline CP & $90 \pm 0.8$ & $<0.001$ & $35.34 \pm 9.91$ & 0.001
\end{tabular}

Indispensable AA

$\begin{array}{lllll}\text { Arg } & 93 \pm 0.6 & <0.001 & 1.22 \pm 0.35 & 0.001 \\ \text { His } & 83 \pm 0.7 & <0.001 & 0.34 \pm 0.16 & 0.040 \\ \text { He } & 93 \pm 0.6 & <0.001 & 1.10 \pm 0.22 & <0.001 \\ \text { Leu } & 86 \pm 0.5 & <0.001 & 1.29 \pm 0.39 & 0.002 \\ \text { Lys } & 79 \pm 0.9 & <0.001 & 1.08 \pm 0.35 & 0.003 \\ \text { Met } & 85 \pm 0.5 & <0.001 & 0.25 \pm 0.09 & 0.009 \\ \text { Phe } & 92 \pm 0.4 & <0.001 & 1.27 \pm 0.21 & <0.001 \\ \text { Thr } & 79 \pm 1.0 & <0.001 & 1.02 \pm 0.40 & 0.013 \\ \text { Trp } & 86 \pm 0.7 & <0.001 & 0.38 \pm 0.10 & 0.001 \\ \text { Val } & 83 \pm 0.6 & <0.001 & 0.89 \pm 0.35 & 0.013\end{array}$

Dispensable AA

\begin{tabular}{lllll} 
Ala & $77 \pm 1.2$ & $<0.001$ & $1.18 \pm 0.55$ & 0.037 \\
Asp & $81 \pm 1.0$ & $<0.001$ & $1.86 \pm 0.64$ & 0.005 \\
Cys & $87 \pm 0.4$ & $<0.001$ & $0.43 \pm 0.11$ & $<0.001$ \\
Glu & $94 \pm 0.4$ & $<0.001$ & $3.44 \pm 0.99$ & 0.001 \\
Gly & $84 \pm 1.4$ & $<0.001$ & $2.05 \pm 0.64$ & 0.002 \\
Pro & $95 \pm 0.7$ & $<0.001$ & $3.35 \pm 0.84$ & $<0.001$ \\
Ser & $91 \pm 0.9$ & $<0.001$ & $1.35 \pm 0.45$ & 0.004 \\
\hline
\end{tabular}

${ }^{*} P$-values of the estimates for the slope of the regression equations; ${ }^{* *} P$-values of the estimates for the intercepts of the regression equation

more reliable estimates of $\mathrm{IAA}_{\text {end }}$ can be obtained. Thus, extrapolation of $\mathrm{IAA}_{\text {end }}$ from a dietary $\mathrm{CP}$ level of $109.1 \mathrm{~g} / \mathrm{kg}$ DM to zero CP intake may be associated with some uncertainties as also indicated by the large standard error in the present study. On the other hand, all estimates of $\mathrm{IAA}_{\text {end }}$ obtained in the present study were significantly different from zero, which is in agreement with the results of several other studies, where dietary $\mathrm{CP}$ levels of approximately $100 \mathrm{~g} / \mathrm{kg}$ assay diet resulted in significant estimates of IAA $_{\text {end }}$ associated with large standard errors [3, 13, 34, 36, 41, 42]. However, at smaller dietary CP below $50 \mathrm{~g} / \mathrm{kg}$, total ( $\mathrm{IAA}_{\text {end }}$ + feed specific) endogenous losses may increase in a nonlinear manner with increasing dietary inclusion level of the assay feed ingredient [43]. Therefore, the range of CP levels in the present study, above this critical level, is more reliable than a wider range, that includes considerably lower CP levels, closer to the coordinate.

Furthermore, feeding of $\mathrm{N}$-free diets or low protein diets over a prolonged period of time can result in increased ileal endogenous AA recovery [37, 44], mainly due to elevated endogenous Pro loss. According to Jansman et al. [8], a Pro content exceeding $30 \%$ of the total quantity of AA in ileal digesta points towards non-physiological conditions. In the present study, a crystalline AA mixture was added on top of the assay diets during the initial $3.5 \mathrm{~d}$ of every period as suggested by Pedersen et al. [15] to attenuate any possible effects of the low-protein barleybased assay diets on estimates of IAA $A_{\text {end }}$. As a result, Pro contributed only $15 \%$ to total protein recovery in ileal digesta of pigs, thus a normal physiological state can be assumed. Therefore it is rather unlikely, that the observed high $\mathrm{IAA}_{\text {end }}$ in the present study is due to the low protein content of the barley assay diets.

Standardized ileal digestibility of $\mathrm{CP}$ and AA in the present study was consistently between 6 and $19 \%$ greater than mean SID of CP and AA reported by Spindler et al. [7], where SID values were determined in the same eight barley genotypes by correcting AID values for IAA $_{\text {end }}$ obtained by the $\mathrm{N}$-free alimentation method [8]. Furthermore, compared to tabulated SID values for barley [30, 45], SID values of $\mathrm{CP}$ and most $\mathrm{AA}$ reported herein were greater, in part close to values for wheat [16] or protein ingredients such as soybean meal [30]. However, greater SID values in the present experiment compared to tabulated values are most likely not caused by differences in chemical composition, as no significant effects of chemical composition on regression analysis could be observed. Similar to the findings of the present work, recent studies with wheat [11], rye [9], and triticale [10] revealed greater SID values by means of the regression method compared to SID values obtained by correction of AID values for IAA $\mathrm{And}_{\text {end }}$. In support of these findings, Spindler et al. [3] and Fan and Sauer [34] reported greater $\mathrm{IAA}_{\text {end }}$, determined by regression analysis, associated with barley and other cereal grains compared to those obtained by $\mathrm{N}$-free feeding or the use of highly digestible diets. Thus, differences between SID values derived from regression analysis and SID values obtained by correcting AID values for IAA $_{\text {end }}$ can mainly be attributed to variations in IAA $_{\text {end }}$ values. Estimation of SID of AA by regression analysis requires significant linear relationships between AID and total dietary contents of $\mathrm{CP}$ and AA. Therefore, the relative small range of dietary $\mathrm{CP}$ levels from 109.1 to $123.8 \mathrm{~g} / \mathrm{kg}$ DM may result in some uncertainty for the estimates of SID of CP and AA as indicated by large standard errors in the present study. However, highly $(P<0.001$; except for Gly, where $P<0.03)$ significant linear relationships between AID and total dietary contents of $\mathrm{CP}$ and $\mathrm{AA}$ were obtained. Moreover, there is evidence, that the range of dietary $\mathrm{CP}$ levels had only minor impact on estimates of SID of AA [13].

The use of $\mathrm{N}$-free diets has been accepted as a routine procedure in generating SID of CP and AA in feed ingredients [6]. In particular at low levels of $\mathrm{CP}$ in the assay diets, correction of AID values for their IAA $_{\text {end }}$ can easily result in an over- or underestimation of SID values due to the substantial correction effect for IAA $_{\text {end }}$ at low dietary CP levels, as IAA $_{\text {end }}$ have been shown to 
vary greatly between and within animals and experiments (e.g. [46]). In contrast, the slopes of the linear regression between dietary contents of apparent ileal digestible and total $\mathrm{CP}$ and AA provide direct estimates of SID without need for a separate consideration of IAA $_{\text {end }}$.

\section{Conclusion}

Basal ileal endogenous losses of $\mathrm{CP}$ and AA resulting from the regression between CAID and total dietary contents of AA are considerably greater in cereal grains including barley, compared to reports on IAA $_{\text {end }}$ obtained from $\mathrm{N}$-free alimentation. Furthermore, the results of the present study show that SID of CP and AA in cereal grains such as barley determined by regression analysis is substantially greater (up to $14 \%$ ) compared to previously reported SID values in feed tables. These differences may be attributed to varying estimates of $\mathrm{IAA}_{\text {end }}$ among studies. For low-protein feed ingredients including cereals such as barley, the regression method, where SID values are directly obtained from the slope of the linear regression model, may be preferred over correction of AID values for $\mathrm{IAA}_{\text {end }}$ determined under $\mathrm{N}$-free feeding conditions.

\section{Abbreviations \\ AA: Amino acid; ADF: Acid detergent fiber; ADFom: Acid detergent fiber expressed exclusive of residual ash; ADL: Acid detergent lignin; AID: Apparent ileal digestibility; aNDF: Neutral detergent fiber with heat stable amylase and expressed exclusive residual ash; BW: Body weight; CAID: Apparent ileal digestible content; CP: Crude protein; DM: Dry matter; DMI: Dry matter intake; GE: Gross energy; IAA end: Basal ileal endogenous losses; N: Nitrogen; NDF: Neutral detergent fiber; NSP: Non-starch polysaccharides; SID: Standardized ileal digestibility}

\section{Funding}

The project was supported in the framework of GrainUp by funds of the Federal Ministry of Food, Agriculture, and Consumer Protection (BMELV) based on a decision of the Parliament of the Federal Republic of Germany via the Federal Office for Agriculture Food and (BLE) under the innovation support program.

\section{Availability of data and materials}

All data generated or analyzed during this study are available from the corresponding author on reasonable request.

\section{Authors' contributions}

HKS, RM and ME conceived the study, performed the statistics and drafted the manuscript. PR and HJ participated in animal experiments. KEBK conducted the chemical analysis of carbohydrates. All authors read and approved the final manuscript.

\section{Competing interests}

The authors declare that they have no competing interests.

\section{Consent for publication}

Not applicable.

\section{Ethics approval and consent to participate}

Experimental protocols complied with the guidelines of the Danish Animal Experiments Inspectorate, Ministry of Justice, Copenhagen, Denmark, with respect to animal experimentation and care of the animals under study. The experiment was conducted at Aarhus University (Department of Animal Science, Research Center Foulum, Tjele, Denmark).

\section{Author details}

'University of Hohenheim, Institute of Animal Science, Emil-Wolff-Strasse 10, 70599 Stuttgart, Germany. ${ }^{2}$ Aarhus University, Department of Animal Science, Research Center Foulum, 8830 Tjele, Denmark.

Received: 2 February 2016 Accepted: 10 September 2016

Published online: 26 September 2016

\section{References}

1. FAOSTAT. Food and Agriculture Organization of the United Nations. 2013. http://faostat.fao.org/site/535/default.aspx\#ancor. Accessed 3 July 2015.

2. Myrie SB, Bertolo RF, Sauer WC, Ball RO. Effect of common antinutritive factors and fibrous feedstuffs in pig diets on amino acid digestibilities with special emphasis on threonine. J Anim Sci. 2008;86:609-19. doi:10.2527/jas.2006-793.

3. Spindler HK, Mosenthin R, Eklund M. Evaluation through literature data on standardized ileal digestibility and basal ileal endogenous loss of amino acids associated with barley in pigs. Anim. 2014a;8:1603-11. doi:10.1017/S1751731114001438

4. De Vries S, Pustjens AM, Schols HA, Hendriks WH, Gerrits WJJ. Improving digestive utilization of fiber-rich feedstuffs in pigs and poultry by processing and enzyme technologies: a review. Anim Feed Sci Technol. 2012;178:123-38. doi:10.1016/j.anifeedsci.2012.10.004.

5. Rosenfelder P, Eklund M, Mosenthin R. Nutritive value of wheat and wheat by-products in pig nutrition: a review. Anim Feed Sci Tech. 2013;185:107-25. doi:10.1016/j.anifeedsci.2013.07.011.

6. Stein HH, Sève B, Fuller MF, Moughan PJ, de Lange CFM. Invited review: amino acid bioavailability and digestibility in pig feed ingredients: terminology and application. J Anim Sci. 2007;85:172-80. doi:10.2527/jas.2005-742.

7. Spindler HK, Mosenthin R, Rosenfelder P, Jørgensen H, Bach Knudsen KE, Sauer N, et al. Standardized ileal digestibility of amino acids in eight genotypes of barley fed to growing pigs. Anim. 2016;1-10. http://dx.doi.org/ 10.1017/S175173111600104X

8. Jansman AJM, Smink W, van Leeuwen P, Rademacher M. Evaluation through literature data of the amount and amino acid composition of basal endogenous crude protein at the terminal ileum. Anim Feed Sci Technol. 2002;98:49-60. doi:10.1016/S0377-8401(02)00015-9.

9. Eklund M, Strang E, Rosenfelder P, Sauer N, Htoo J, Mosenthin R. Ileal endogenous losses and standardized ileal digestibility of amino acids in rye genotypes for pigs. Book of abstracts - digestive physiology of pigs. 2015. p. 227 (2.74).

10. Strang E, Eklund M, Rosenfelder P, Sauer N, Htoo J, Mosenthin R. Standardized ileal digestibility and basal ileal endogenous loss of amino acids associated with triticale genotypes in growing pigs. Book of abstracts - digestive physiology of pigs. 2015. p. 229 (2.76).

11. Rosenfelder P, Eklund M, Spindler H, Jørgensen H, Bach Knudsen KE, Sauer N, et al. Determination of basal ileal endogenous loss and standardized ileal digestibility of amino acids in wheat for pigs. Book of abstracts - digestive physiology of pigs. 2015a. p. 228 (2.75).

12. Fan MZ, Sauer WC, McBurney MI. Estimation by regression analysis of endogenous amino acid levels in digesta collected from the distal ileum of pigs. J Anim Sci. 1995;73:2319-28. doi:/1995.7382319x.

13. Eklund M, Mosenthin R, Piepho HP, Rademacher M. Estimates of basal ileal endogenous losses of amino acids by regression analysis and determination of standardized ileal amino acid digestibilities from casein in newly weaned pigs. J SciFood Agric. 2008b;88:641-51. doi:10.1002/jsfa.3129.

14. National Research Council (NRC). Nutrient requirements of swine. 10th ed. Washington DC: National Academies Press; 1998.

15. Pedersen C, Boersma MG, Stein HH. Energy and nutrient digestibility in NutriDense corn and other cereal grains fed to growing pigs. J Anim Sci. 2007;85:2473-83. doi:10.2527/jas.2006-620.

16. Rosenfelder P, Mosenthin R, Spindler HK, Jørgensen H, Bach Knudsen KE, et al. Standardized ileal digestibility of amino acids in eight genotypes of soft winter wheat fed to growing pigs. J Anim Sci. 2015b;93:1133-44. doi:10. 2527/jas.2014-8079.

17. VDLUFA (Verband Deutscher Landwirtschaftlicher Untersuchungs- und Forschungsanstalten). Handbuch der Landwirtschaftlichen Versuchs- und Untersuchungsmethodik (VDLUFA-Methodenbuch), Bd. III. Die chemische Untersuchung von Futtermitteln. Darmstadt: VDLUFA-Verlag; 2006.

18. Bach Knudsen KE. Carbohydrate and lignin contents of plant materials used in animal feeding. Anim Feed Sci Tech. 1997;67:319-38. doi:10.1016/S0377-8401(97)00009-6. 
19. Theander O, Westerlund EA. Studies on dietary fiber. 3. Improved procedures for analysis of dietary fiber. J Agric Food Chem. 1986;34:330-6. doi:10.1021/jf00068a045.

20. Hatfield RD, Jung HG, Ralph J, Buxton DR, Weimer PJ. A comparison of the insoluble residues produced by the Klason lignin and acid detergent lignin procedures. J Sci Food Agric. 1994:65:51-8. doi:10.1002/jsfa.2740650109.

21. Jung HG, Mertens DR, Payne AJ. Correlation of acid detergent lignin and klason lignin with digestibility of forage dry matter and neutral detergent fiber. J Dairy Sci. 1997;80:1622-8. doi:10.3168/jds.S0022-0302(97)76093-4.

22. McCleary BV, Glennie-Holmes M. Enzymatic quantification of (1-3) (1-4)- $\beta$ D-glucan in barley and malt. J Inst Brew. 1985;91:285-95.

23. Åman P, Graham H. Analysis of total and insoluble mixed-linked (1-3), (1-4)beta-D-glucans in barley and oats. J Agric Food Chem. 1987;35:704-9. doi:10.1021/jf00077a016

24. Association of Official Analytical Chemists International (AOAC International). Offical methods of analysis. 17th ed. Gaithersburg; 2000.

25. Llames CR, Fontaine J. Determination of amino acids in feeds: collaborative study. J Assoc Off Anal Chem Intern. 1994;77:1362-402

26. Commission Directive. Establishing community methods for the determination of amino-acids, crude oils and fats, and olanquindox in feeding stuff and amending Directive 71/393/EEC, annex part A. Determination of Amino Acids. Official J Europ Comm. 1998;L257:14-23.

27. Commission Directive. Establishing community methods for the determination of vitamin A, vitamin E and tryptophan in feedingstuffs. Annex part C. Determination of tryptophan. Official J Europ Comm. 2000;L174:45-50.

28. Brandt $\mathrm{M}$, Allam SM. Analytik von $\mathrm{TiO}_{2}$ im Darminhalt und Kot nach Kjeldahlaufschluss. Arch Anim Nutr. 1987;37:453-4.

29. SAS. SAS/STAT. User's guide, version 9.2. Cary: SAS Inst., Inc; 2008.

30. National Research Council (NRC). Nutrient requirements of swine. 11th ed. Washington DC: National Academies Press; 2012.

31. Baidoo SK, Liu YG. Hull-less barley for swine: ileal and faecal digestibility of proximate nutrients, amino acids and non-starch polysaccharides. J Sci Food Agric. 1998;76:397-403. doi:10.1002/(SICI)1097-0010(199803)76:3.

32. Holtekjølen AK, Uhlen AK, Bråthen E, Sahlstrøm S, Knutsen SH. Contents of starch and non-starch polysaccharides in barley varieties of different origin. Food Chem. 2006:94:348-58. doi:10.1016/j.foodchem.2004.11.022.

33. Taverner MR, Hume ID, Farrell DJ. Availability to pigs of amino acids in cereal grains. 1. Endogenous levels of amino acids in ileal digesta and faeces of pigs given cereal diets. Br J Nut. 1981;46:149-58. doi:10.1079/BJN19810017.

34. Fan $M Z$, Sauer WC. Determination of true ileal amino acid digestibility and the endogenous amino acid outputs associated with barley samples for growing-finishing pigs by the regression analysis technique. J Anim Sci. 2002;80:1593-605. /2002.8061593x.

35. Pedersen S, Boisen S, Fernández JA. Studies on the effect of dietary crude protein supply on the composition of ileal endogenous crude protein loss in growing pigs. Acta Agric Scand Sect A, Anim Sci. 2002;52:141-9. doi:10. 1080/090647002320229383.

36. Eklund M, Mosenthin R, Piepho HP, Rademacher M. Effect of dietary crude protein level on basal ileal endogenous losses and standardized ileal digestibilities of crude protein and amino acids in newly weaned pigs. J Anim Phys Anim Nutr. 2008a;92:578-90. doi:10.1111/j.1439-0396.2007.00751.x.

37. De Lange CFM, Sauer WC, Mosenthin R, Souffrant WB. The effect of feeding different protein-free diets on the recovery and amino acid composition of endogenous protein collected from the distal ileum and feces in pigs. J Anim Sci. 1989:67:746-54. doi:10.2134/jas1989.673746x.

38. De Lange CFM, Souffrant WB, Sauer WC. Real ileal protein and amino acid digestibilities in feedstuffs for growing pigs as determined with the $15 \mathrm{~N}$ isotope dilution technique. J Anim Sci. 1990;68:409-18. doi:/1990.682409x

39. Mariscal-Landín G, Séve B, Colleaux Y, Lebreton Y. Endogenous amino nitrogen collected from pigs with end-to-end ileorectal anastomosis is affected by the method of estimation and altered by dietary fiber. J Nutr. 1995; 125:136-46

40. Jondreville C, van den Broecke J, Gâtel F, Grosjean F, van Cauwenberghe S, Séve B. lleal digestibility of amino acids and estimated of endogenous amino acid losses in pigs fed wheat, triticale, rye, barley, maize and sorghum. Anim Res. 2001;50:119-34. doi:10.1051/animres:2001120.

41. Donkoh A, Moughan PJ, Morel PCH. Comparison of methods to determine the endogenous amino acid flow at the terminal ileum of the growing rat. J Sci Food Agric. 1995;67(3):359-66. doi:10.1002/jsfa.2740670313.
42. de Souza TCR, Aguilera BA, Mariscal-Landín G. Estimation of endogenous protein and amino acid ileal losses in weaned piglets by regression analysis using diets with graded levels of casein. J Anim Sci Biotechnol. 2013;4:36. doi:10.1186/2049-1891-4-36.

43. Zhang HL, Qiao SY, Chen XJ, Wang X, Xing JJ, Yin YL. Effects of graded levels of soya-bean protein on endogenous ileal lysine loss and amino acid digestibility in growing pigs. Anim Sci. 2005;81:257-64. doi:10.1079/ASC50240257.

44. Mariscal-Landín G, de Souza TCR. Endogenous ileal losses of nitrogen and amino acids in pigs and piglets fed graded levels of casein. Arch Anim Nutr. 2006;60:454-66. doi:10.1080/17450390600973642.

45. Evonik Degussa. AminoDat ${ }^{\oplus}$ 4.0. Amino acid composition of feedstuffs. Ed. Hanau: Evonik Degussa GmbH; 2010.

46. Eklund M. Methodological considerations for the determination of standardised ileal amino acid digestibilities in piglets. PhD thesis. Germany: University of Hohenheim; 2006.

\section{Submit your next manuscript to BioMed Central and we will help you at every step:}

- We accept pre-submission inquiries

- Our selector tool helps you to find the most relevant journal

- We provide round the clock customer support

- Convenient online submission

- Thorough peer review

- Inclusion in PubMed and all major indexing services

- Maximum visibility for your research

Submit your manuscript at www.biomedcentral.com/submit
) Biomed Central 